\title{
Effects of bud nodal position along the cane on bud fertility, yield component and bunch structure in 'Carménēre' grapevines
}

\author{
Gastōn Gutiērrez-Gamboa1, Irina Díaz-Gálvez², and Yerko Moreno-Simunovic ${ }^{1 *}$ \\ ${ }^{1}$ Universidad de Talca, Facultad de Ciencias Agrarias, Av. Lircay S/N, Talca, Chile. "Corresponding author (ymoreno@utalca.cl). \\ ${ }^{2}$ Instituto de Investigaciones Agropecuarias, INIA Raihuén, Casilla 34, San Javier, Chile.
}

Received: 21 May 2018; Accepted: 11 September 2018; doi:10.4067/S0718-58392018000400580

\begin{abstract}
Carménère is an important grapevine (Vitis vinifera L.) variety from the Chilean wine industry, which has a low fertility in their basal buds, affecting negatively yield. Due to this, the aim of this work was to characterize and evaluate technological maturity, percentage of bud break, practical bud fertility, yield components, bunch structure and yield index by practical fertility reached in each nodal position in buds along Carménère canes. Bud break reached an average of $79.9 \%$ along the cane, with extreme values from $57.3 \%$ to $98.7 \%$. Bud fertility reached an average of 1.3 bunch per bud, with extreme values from 0.9 to 1.7. According to this, 'Carménère' showed a low fertility in basal buds. Weight of bunch varied from 108.0 to $214.7 \mathrm{~g}$. Number and weight of berries was higher in the buds from distal nodal positions. Bunch structure parameters, such as stalk length, number and length of primary wings, and yield index by practical fertility was also higher in the bud from distal nodal positions. Moreover, large size berries represent $50 \%$ of berries and $80 \%$ of weight of berries. Due to this, 'Carménère' productivity is limited by small size berries. These findings are important to determine the viticultural managements that should be performed in 'Carménère' vineyards.
\end{abstract}

Key words: Acrotony, basal and distal positions, bud break, Carménère grapevines, practical bud fertility, Vitis vinifera .

\section{INTRODUCTION}

Carménère (Vitis vinifera L.) variety is one of the most widely cultivated in Chile since its arrival from Bordeaux, France, around the year 1851, before the phylloxera (Dactylosphaera vitifoliae) devastation of European grapevines. During most of the 20th century 'Carménère' was inadvertently harvested and winemaking together with 'Merlot' (Pszczólkowsky, 2004). Subsequently, 'Carménère' was rediscovered in Chile around 1994, through ampelographic and DNA analyses (Pszczólkowsky, 2004). Currently, this variety is recognized as emblematic in Chile due to its economic importance and international relevance (Pszczólkowsky, 2008). 'Carménère' surface accounting 10503 ha reaching a 7.65\% of the national average surface (SAG, 2015). 'Carménère' is a very vigorous cultivar characterized by late entering into production, which present a low fertility in their basal buds. These problems force to use a cane pruning over spur pruning. Along with this, 'Carménère' exhibits a high tendency to fruitlet abscission and "millerandage", reproductive disorders that seriously affect productivity (Alva et al., 2015). This is a viticultural hazard problem in which there is an incomplete fertilization in fruit set, so that the grape bunches contain berries that differ greatly in size and maturity (Alva et al., 2015).

Grapevine productivity of next year is determined by the induction and differentiation of grapevine inflorescence primordia occurred soon after bud break of the current season (May and Antcliff, 1963; Sánchez and Dokoozlian, 2005; Wilkie et al., 2008). During this step, an excessive sunlight exposure of the interior of the canopy can cause sunburn of the current season's fruit, while much shade is associated with low bud fruitfulness during the following season 
(May et al., 1976; Sánchez and Dokoozlian, 2005). In this way, it has been reported that shoot light microclimate was significantly correlated with potential fruitfulness (Sánchez and Dokoozlian, 2005). Bud fertility is defined as the number of inflorescences present by bud (Martínez de Toda, 1991; Vaillant-Gaveau et al., 2014). Thus, along a fruit cane, the bud fertility has a characteristic pattern for each cultivar (Sánchez and Dokoozlian, 2005). Bud fertility tends to increase from the base to the middle portion of the cane, where the highest values of bud fertility are reached, from which it begins to decrease (Reynier, 2002; Ferrer et al., 2004). Moreover, it has been reported that grapevine bud fertility and number of berries per bunch are determined by water and $\mathrm{N}$ stress around flowering in the previous year (Guilpart et al., 2014). These variations in bud fertility together with the physiological problems, negatively affect 'Carménère' yield. Due to this, the determination of aforementioned viticultural parameters could be used as an important tool to estimate the grape productivity early in the season. From this, it is possible to define different viticultural managements, according to the productive objective of the vineyard.

Due to the aforementioned, the aim of this work was to characterize and evaluate technological maturity, percentage of bud break, practical bud fertility, yield components, bunch structure and yield index by practical fertility reached in buds from different nodal position along the cane in 'Carménère' grapevines.

\section{MATERIALS AND METHODS}

\section{Experimental site and plant material}

The field study was conducted in a commercial 'Carménère' vineyard located in San Javier ( $35^{\circ} 37^{\prime}$ S; $71^{\circ} 46^{\prime}$ ' W), Maule Valley, Chile. Vineyard surface accounted 1.35 ha and was planted in 2000 in a north-south orientation, at a distance of 2.5 $\mathrm{m}$ between rows and $1.5 \mathrm{~m}$ between plants, considering a total of 2666 vines ha $\mathrm{a}^{-1}$. Grapevines were trained to a vertically shoot positioned system. Respect to the irrigation, the vineyard has drip irrigation, with an output per plant of $4 \mathrm{Lh}^{-1}$. The soil is clay loam classified as Futic Haploxerolls (Mollisol), which is characterized by being a sedimentary soil in alluvial terrace position, with a flat topography of good drainage and permeability (CIREN, 1997). The effective soil depth was $55 \mathrm{~cm}$. Climate is warm temperate and present a dry season along summer. Precipitations reached around of $824.1 \mathrm{~mm}$. Frost free period reached around of 10-mo. Average annual maximum temperature was $25.2^{\circ} \mathrm{C}$ and the average minimum temperature was $5.1^{\circ} \mathrm{C}$

\section{Statistical design and sample evaluations}

The experimental design used in the present work was completely randomized (CRD). Twelve treatments were defined, each one identified with a nodal position of bud within the cane. The unit of analysis consisted in 20 different canes per treatment.

During the second week of December the following parameters were measured along the cordons: bud break was determined as the number of emerged buds by each nodal position, and bud fertility or practical bud fertility was measured as the number of inflorescences by each emerged bud, as was stated by Reynier (2002). At harvest, different parameters were measured in grapes. ${ }^{\circ} \mathrm{Brix}, \mathrm{pH}$, and total acidity ( $\mathrm{g} \mathrm{L}^{-1}$ sulfuric acid) were analyzed according to the methodology stablished by OIV (2003). Bunch weight, weight and number of berries per bunch, stalk length, number and length of primary wings per bunch, and distribution of berries (number and weight) along the bunch by caliber were analyzed according to the exposed by OIV (2001). Bunch weight was evaluated using an analytical balance (Cubis Precision Balance, Sartorius, Göttingen, Germany). Distribution of grape berries by caliber was measured using a sieve with three different levels, after separation of all grapes from the bunch. Separation by caliber had three ranges: high size from 16 to $12 \mathrm{~mm}$, medium size from 12 to $8 \mathrm{~mm}$, and small size from 8 to $4 \mathrm{~mm}$. Subsequently, obtained berries by each range were weighed using the analytical balance.

Yield index by practical bud fertility (YIPF) was calculated multiplying bunch weight and practical bud fertility data, which quantify the grape productivity (g) produced by the buds from different nodal position along the cane (Equation [1]).

$$
\text { YIPF }=\text { Weight of bunch }\left(\mathrm{g} \mathrm{bunch}^{-1}\right) \times \text { practical bud fertility }\left(\text { bunch bud }{ }^{-1}\right)=\mathrm{g} \mathrm{bud}^{-1}
$$




\section{Statistical analysis}

The statistical analysis in relation to parameters analyzed was performed using one-way ANOVA, by Centurion XVI.I (Statgraphics Technologies; The Plains, Virginia, USA). Differences between samples were compared using the Duncan test at $95 \%$ probability level.

\section{RESULTS AND DISCUSSION}

\section{Characterization of technological maturity}

${ }^{\circ} \mathrm{Brix}, \mathrm{pH}$, and total acidity reached in the grapes obtained from the different nodal positions had nonsignificant differences among them (Table 1). Soluble solids ranged from 21.2 to $24.8^{\circ} \mathrm{Brix}$ (in the first and $12^{\text {th }}$ nodal positions, respectively). It seems that grapes from basal nodes presented a lower concentration of soluble solids possibly due to the presence of shoots with high vigor in the basal nodal positions. $\mathrm{pH}$ varied from 3.4 to 3.8 (in the first and $11^{\text {th }}$ nodal positions, respectively). Total acidity varied from 2.7 to $3.4 \mathrm{~g} \mathrm{~L}^{-1}$ sulfuric acid (in the $8^{\text {th }}$ and second nodal positions, respectively).

\section{Characterization of bud break and practical bud fertility}

Bud break (\%) and practical bud fertility (bunches bud ${ }^{-1}$ ) had significant differences among the nodal positions (Table 1). Bud break varied from $57.3 \%$ to $98.7 \%$ (in the first and $12^{\text {th }}$ nodal positions, respectively), while practical bud fertility ranged from 0.88 to 1.69 bunches bud $^{-1}$ (in the first and $11^{\text {th }}$ nodal positions, respectively). According to the second edition of the OIV Descriptor List for Grape Varieties and Vitis Species, fertility of basal buds in 'Carménère' is classified as very low (OIV, 2001). Bud break percentage was higher in the $12^{\text {th }}$ than the $1^{\text {st }}, 2^{\text {nd }}, 4^{\text {th }}$ to $7^{\text {th }}$ and $8^{\text {th }}$ nodal positions, while bud fertility was higher in the $11^{\text {th }}$ than the first to $6^{\text {th }}$ and $8^{\text {th }}$ nodal positions. These results evidenced the marked acrotony presented by this grapevine variety (Pszczólkowsky, 2004), enhanced by its high vigor and the low fertility presented in their basal buds. Thus, the distal nodal positions showed a higher bud break and practical bud fertility than the basal nodal positions, as was reported in others grapevine varieties (López-Miranda et al., 2004; Carmo Vasconcelos et al., 2009). Both trends are observed in Figure 1.

Table 1. Technological maturity, bud break, practical bud fertility, yield component and bunch structure by each nodal position in Carménère canes.

\begin{tabular}{|c|c|c|c|c|c|c|c|c|c|c|c|}
\hline \multirow[b]{2}{*}{$\begin{array}{l}\text { Nodal } \\
\text { position }\end{array}$} & \multicolumn{3}{|c|}{ Technological maturity } & \multicolumn{2}{|c|}{$\begin{array}{c}\text { Bud break and } \\
\text { practical fertility }\end{array}$} & \multicolumn{3}{|c|}{ Yield component } & \multicolumn{3}{|c|}{ Bunch structure } \\
\hline & ${ }^{\circ}$ Brix & $\mathrm{pH}$ & $\begin{array}{c}\text { Total } \\
\text { acidity }^{\mathrm{a}}\end{array}$ & $\begin{array}{l}\text { Bud } \\
\text { break }\end{array}$ & $\begin{array}{c}\text { Bud } \\
\text { fertility }^{\mathrm{b}}\end{array}$ & $\begin{array}{l}\text { Weight of } \\
\text { bunch }\end{array}$ & $\begin{array}{l}\mathrm{Nr} \text { berries } \\
\text { per bunch }\end{array}$ & $\begin{array}{c}\text { Weight of } \\
\text { berries }\end{array}$ & $\begin{array}{l}\text { Stalk } \\
\text { length }\end{array}$ & $\begin{array}{l}\text { Length of } \\
\text { primary } \\
\text { wings }\end{array}$ & $\begin{array}{c}\text { Nr primary } \\
\text { wings per } \\
\text { bunch }\end{array}$ \\
\hline & & & $\mathrm{g} \mathrm{L}^{-1}$ & $\%$ & & $\mathrm{~g}$ & & $\mathrm{~g}$ & $\mathrm{~cm}$ & $\mathrm{~cm}$ & \\
\hline 1 & 21.2 & 3.4 & 3.1 & $57.3 \mathrm{~d}$ & $0.88 \mathrm{~g}$ & $108.0 \mathrm{f}$ & $103.6 \mathrm{~g}$ & $1.04 \mathrm{c}$ & $17.0 \mathrm{~d}$ & $3.5 \mathrm{~g}$ & $2.2 \mathrm{f}$ \\
\hline 2 & 22.2 & 3.4 & 3.4 & $76.0 \mathrm{c}$ & $0.91 \mathrm{fg}$ & $146.3 \mathrm{~cd}$ & $121.0 \mathrm{ef}$ & $1.21 \mathrm{~b}$ & $15.0 \mathrm{e}$ & $3.7 \mathrm{f}$ & $2.7 \mathrm{ef}$ \\
\hline 3 & 24.0 & 3.5 & 3.3 & $85.3 \mathrm{abc}$ & $1.12 \mathrm{efg}$ & $120.0 f$ & $114.3 \mathrm{fg}$ & $1.05 \mathrm{c}$ & $17.8 \mathrm{~cd}$ & $4.0 \mathrm{de}$ & $2.8 \mathrm{def}$ \\
\hline 4 & 24.0 & 3.7 & 3.0 & $81.3 b c$ & $1.14 \mathrm{ef}$ & $124.3 \mathrm{ef}$ & $136.0 \mathrm{cde}$ & $0.92 \mathrm{fg}$ & $17.4 \mathrm{~cd}$ & $3.8 \mathrm{f}$ & $2.8 \mathrm{def}$ \\
\hline 5 & 24.8 & 3.7 & 2.9 & $72.0 \mathrm{~cd}$ & $1.29 \mathrm{cde}$ & $128.7 \mathrm{def}$ & 128.0def & $1.00 \mathrm{cde}$ & $17.8 \mathrm{~cd}$ & $3.8 \mathrm{f}$ & $3.3 \mathrm{cde}$ \\
\hline 6 & 23.2 & 3.7 & 2.9 & $73.3 \mathrm{~cd}$ & $1.19 \mathrm{de}$ & $118.3 \mathrm{f}$ & $134.0 \mathrm{cde}$ & $0.88 \mathrm{~g}$ & $17.6 \mathrm{~cd}$ & $3.9 \mathrm{ef}$ & $2.7 \mathrm{ef}$ \\
\hline 7 & 23.6 & 3.7 & 3.2 & $73.3 \mathrm{~cd}$ & $1.50 \mathrm{abc}$ & $141.3 \mathrm{cde}$ & $147.0 \mathrm{bc}$ & $0.96 \mathrm{ef}$ & $18.4 \mathrm{bc}$ & $4.1 \mathrm{~d}$ & $3.4 \mathrm{~cd}$ \\
\hline 8 & 24.0 & 3.8 & 2.7 & $74.7 \mathrm{c}$ & $1.40 \mathrm{bcd}$ & 119.0f & $133.3 \mathrm{cde}$ & $0.89 \mathrm{~g}$ & $17.9 \mathrm{~cd}$ & $4.2 \mathrm{c}$ & $2.8 \mathrm{def}$ \\
\hline 9 & 22.8 & 3.7 & 2.9 & $85.3 \mathrm{abc}$ & $1.61 \mathrm{ab}$ & $146.7 \mathrm{~cd}$ & $141.7 \mathrm{bcd}$ & $1.04 \mathrm{~cd}$ & $18.5 b c$ & $4.5 b$ & $3.9 b c$ \\
\hline 10 & 23.8 & 3.8 & 2.9 & $84.0 \mathrm{abc}$ & $1.61 \mathrm{ab}$ & $154.7 \mathrm{c}$ & $155.3 \mathrm{ab}$ & 0.99de & $19.2 b$ & $4.5 b$ & $4.3 \mathrm{ab}$ \\
\hline 11 & 24.0 & 3.8 & 2.8 & $97.3 \mathrm{ab}$ & $1.69 \mathrm{a}$ & $214.7 \mathrm{a}$ & $170.0 \mathrm{a}$ & $1.26 \mathrm{a}$ & $19.2 b$ & $5.0 \mathrm{a}$ & $4.4 \mathrm{ab}$ \\
\hline 12 & 24.8 & 3.7 & 3.1 & $98.7 \mathrm{a}$ & $1.59 \mathrm{ab}$ & $192.9 b$ & $148.3 \mathrm{bc}$ & $1.29 \mathrm{a}$ & $20.6 \mathrm{a}$ & $4.6 b$ & $4.7 \mathrm{a}$ \\
\hline Significance & NS & NS & NS & $* *$ & $* *$ & $* *$ & $* *$ & $*$ & $* *$ & $* *$ & $* *$ \\
\hline $\mathrm{CV}$ & 26.7 & 5.6 & 9.3 & 11.1 & 10.6 & 8.2 & 6.7 & 2.7 & 3.5 & 2.2 & 11.0 \\
\hline
\end{tabular}


Figure 1. Variation of the percentage of bud break $\left(r^{2}=0.36\right)$ (a) and practical bud fertility (bunch bud $\left.\mathbf{b}^{-1}\right)\left(\mathrm{r}^{2}=0.78\right)(\mathrm{b})$, according to the nodal position within the Carménère cane.
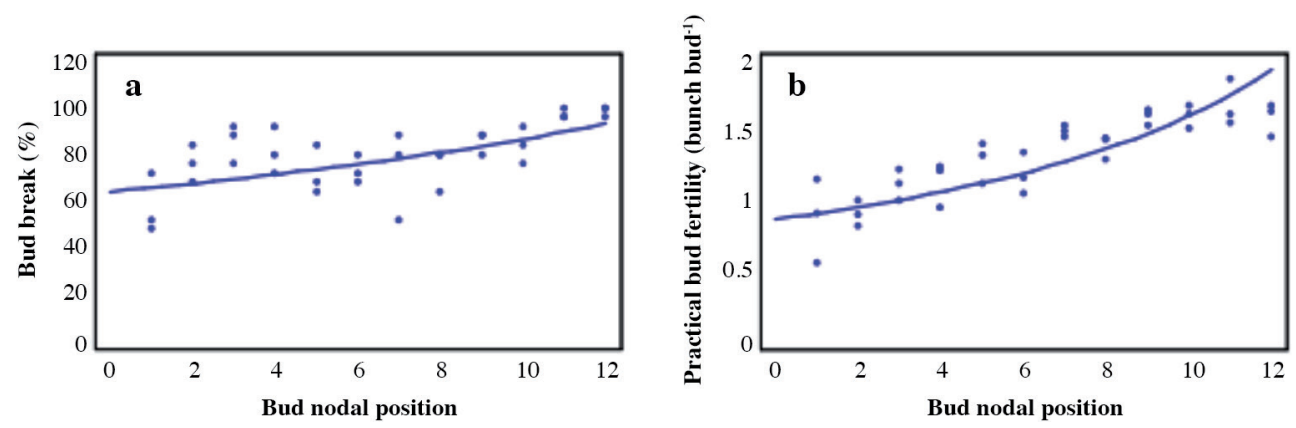

\section{Characterization of yield components}

Yield components had significant differences among the nodal positions (Table 1). Weight of bunch varied from 108.0 to $214.7 \mathrm{~g}$ (in the first and $11^{\text {th }}$ nodal positions, respectively), being classified as low weight (OIV, 2001). Number of berries per bunch ranged from 103.6 to 170.0 (in the first and $11^{\text {th }}$ nodal positions, respectively), while weight of berries varied from 0.88 to $1.29 \mathrm{~g}$ (in the $6^{\text {th }}$ and $12^{\text {th }}$ nodal positions, respectively), being classified as low weight (OIV, 2001). Bunch weight in the $11^{\text {th }}$ nodal position was the highest, and this parameter is defined by the weight of high size berries $\left(r^{2}=0.97\right)$, the number of primary wings per bunch $\left(r^{2}=0.76\right)$ and the number of total berries $\left(r^{2}=0.67\right)$ (Figure 2). Although, bunch weight is mainly defined by the number of berries, this situation did not occur in this work, due probably to the "coulure" and "millerandage" presented along the "Carménère' bunches. This reproductive disorder is characterized

Figure 2. Variation of the bunch weight, according to weight of berries of high size $\left(r^{2}=0.97\right)(a)$, number of primary wings per bunch $\left(r^{2}=0.75\right)(b)$, number of total berries per bunch $\left(r^{2}=0.67\right)(c)$, length of bunch primary wings $\left(r^{2}=0.66\right)$ (d), bud nodal position $\left(r^{2}=0.54\right)(e)$, and stalk length $\left(r^{2}=0.36\right)(f)$.
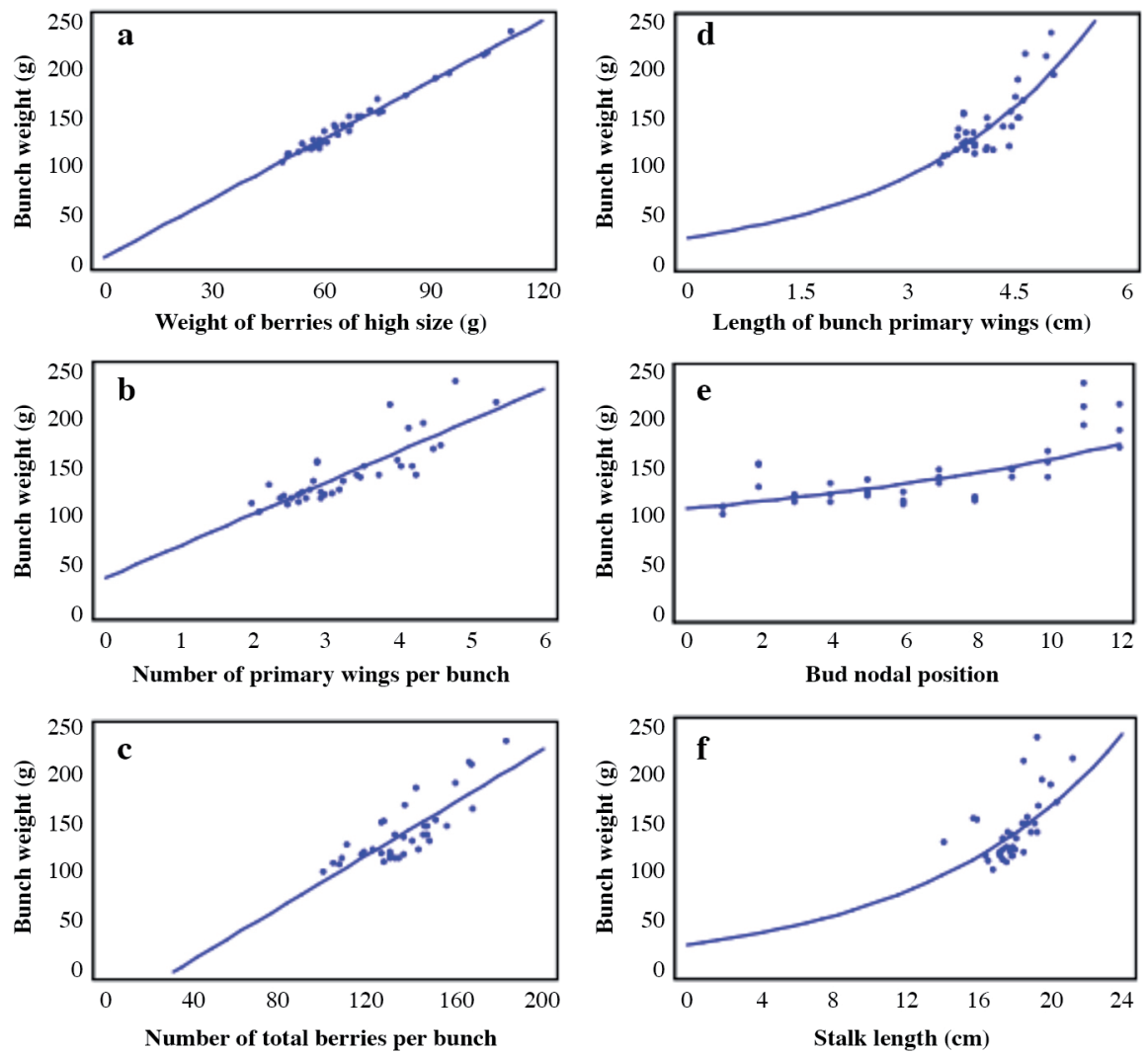
by differ greatly in size and maturity in grape berries (Alva et al., 2015). On the other hand, bunch weight presented regression values of 0.37 for the stalk length, 0.54 for nodal position of bud and 0.66 for the length of primary wings per bunch (Figure 2). Number of berries was higher in the samples obtained from the $11^{\text {th }}$ nodal position than the rest, except to the berries obtained from the $10^{\text {th }}$ nodal position. Respect to the high bunch weight and number of berries per bunch obtained in buds from the distal nodal position, this was probably due to the high degree of ontogenesis achieved in buds from the most distal nodal positions in the previous season, which reached the best light conditions compared to the buds from the basal nodal positions (Sánchez and Dokoozlian, 2005).

\section{Characterization of bunch structure}

Bunch structure parameters had significant differences among the nodal positions (Table 1). Stalk length varied from 15.0 to $20.6 \mathrm{~cm}$ (in the second and $12^{\text {th }}$ nodal positions, respectively), being classified as long length (OIV, 2001). Length of primary wings of the bunch ranged from 3.5 to $5.0 \mathrm{~cm}$ (in the first and $12^{\text {th }}$ nodal positions, respectively), while the number of primary wings per bunch varied from 2.2 to 4.7 (in the first and $12^{\text {th }}$ nodal positions, respectively), being classified in the medium position (OIV, 2001). Samples from the most distal node position presented the highest stalk length, while bunches from the $11^{\text {th }}$ nodal position showed the highest length of primary wings. Besides, bunches from the most distal nodal position presented higher number of primary wings than the samples from the first to $9^{\text {th }}$ nodal positions. As aforementioned, the degree of ontogenesis achieved in buds from the most distal nodal positions in the previous season determine the size of flower primordium and therefore, the number of berries per bunch (Sánchez and Dokoozlian, 2005). Number of berries per bunch was defined by the number of primary wings $\left(r^{2}=0.68\right)$, length of primary wings $\left(r^{2}=0.65\right)$ and stalk length $\left(r^{2}=0.45\right)$ (data not shown). These results indicate that the number of berries per bunch is not mainly defined by the length of the inflorescence, but to its ramification degree.

\section{Distribution of berries by caliber along the 'Carménère' bunch}

Distribution of number and weight of berries per bunch, according to the different calibers (high size: $\geq 10 \mathrm{~mm}$, medium size: 6-10 mm and small size: $\leq 6 \mathrm{~mm}$ ) is shown in the Figures 3a and 3b, respectively. High size berries represented around $50 \%$ of the number of total berries per bunch. Medium size berries represent around of $29 \%$ of total berries, while small size berries represent around of $21 \%$ of total berries per bunch. Respect to its impact on weight, these differences were accentuated. High size berries represented around of $80 \%$ bunch weight. Medium size berries represented around of $17 \%$ bunch weight, while small size berries represented around of $3 \%$ bunch weight. Therefore, around of $80 \%$ productivity in 'Carménère' is defined by the half of the berries present in the bunch. Based on the aforementioned, 'Carménère' production potential is limited to some extent by the growth of berries that do not reach an adequate size. These results reaffirm that a factor that limits production of this cultivar is its tendency to produce "coulure" and "millerandage" in their bunches (Pszczólkowsky, 2004; Alva et al., 2015).

Figure 3. Distribution of number (a) and weight of berries per bunch (b), according to the different calibers (high size: $\geq$ $10 \mathrm{~mm}$, medium size: 6-10 $\mathrm{mm}$ and small size: $\leq 6 \mathrm{~mm}$ ) in Carménère grapevines.

$\mathbf{a}$

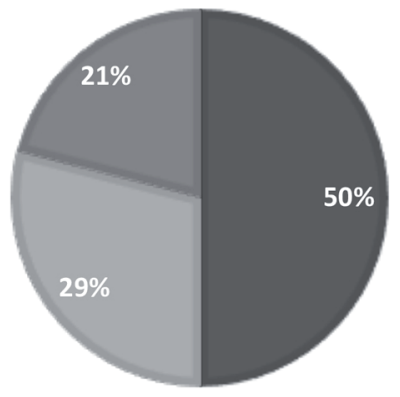

- Large size berries Medium size berries $\mathbf{n}$ Small size berries b

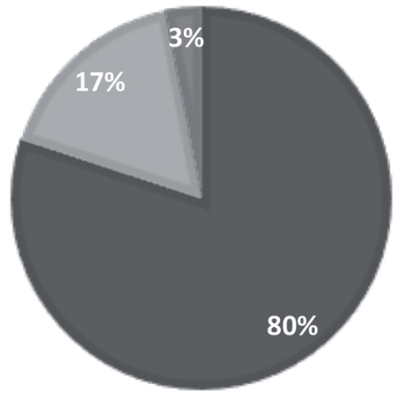

- Large size berries $=$ Medium size berries $=$ Small size berries 
Yield index by practical bud fertility from basal to distal nodal positions

Yield index by practical bud fertility (YIPF) obtained in buds by each nodal position along the cane is shown in Figure 4 and was calculated using bunch weight and practical bud fertility according to the Equation [1]. YIPF showed significant differences among the nodal positions and varied from 95.4 to $364.4 \mathrm{~g} \mathrm{bud}^{-1}$ (in the first and $11^{\text {th }}$ nodal positions, respectively). Eleventh nodal position presented the highest YIPF, followed by the buds from distal nodal position and then, by the buds from $7^{\text {th }}, 9^{\text {th }}$ and $10^{\text {th }}$ nodal positions. As expected, this index progressively increased in buds from basal to distal nodal positions. Based on the aforementioned, 'Carménère' canes should be pruned to avoid losses in grape productivity (Pszczólkowsky, 2004; Gil and Pszczólkowsky, 2007; Fredes et al., 2010).

Figure 4. Yield index by practical bud fertility (YIPF) obtained in buds from each nodal position along the Carménère cane.

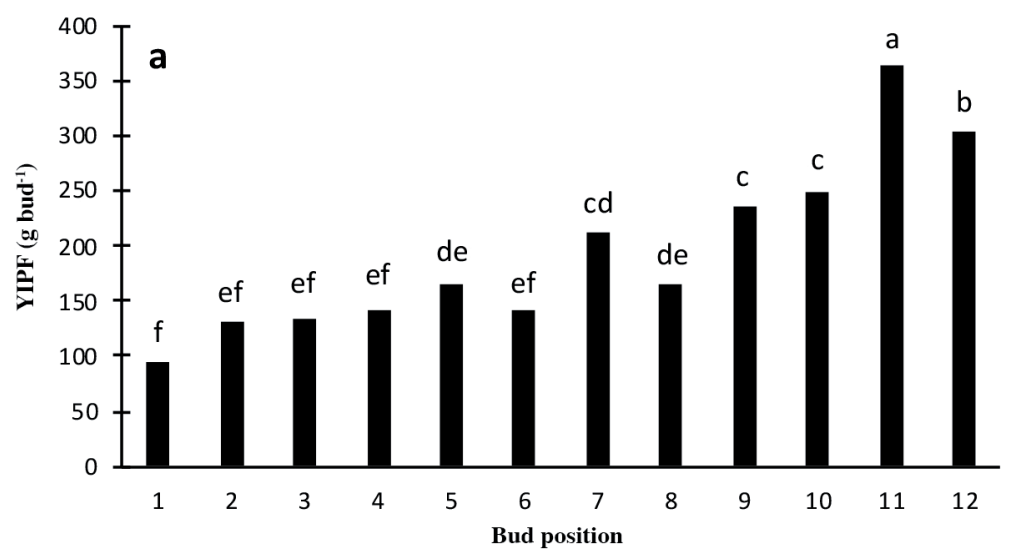

For each nodal position, different letters indicate significant differences $(\mathrm{p} \leq 0.05)$.

\section{CONCLUSIONS}

'Carménère' grapevine presented low values of bud break and practical bud fertility in their basal buds. Distal position of the bud into the cane showed a remarkable superiority in terms of bunch structure, bunch weight and productivity, represented by the yield index by practical bud fertility. In addition, there is a clear tendency to increase all these variables as the bud position moves away from the base of the cane. The presence of "coulure" and "millerandage" in "Carménère' bunches does not allow that the weight of bunches can be related to the number of berries per bunch due to the size heterogeneity of the present berries. Due to this, the presence of a high number of small berries per bunch indicates that a good development of these, would allow a significant increase in productivity. These results may be relevant for the viticultural management of the 'Carménère' vineyards.

\section{ACKNOWLEDGEMENTS}

Gastón Gutiérrez-Gamboa thanks for the financial support given by CONICYT, BCH/Doctorado-72170532.

\section{REFERENCES}

Alva, O., Roa-Roco, R.N, Pérez-Díaz, R., Yáñez, M., Tapia, J., Moreno, Y., et al. 2015. Pollen morphology and boron concentration in floral tissues as factors triggering natural and GA-induced parthenocarpic fruit development in grapevine. PLOS ONE 10:e0139503. doi:10.1371/journal.pone.0139503.

Carmo Vasconcelos, M., Greven, M., Winefield, C.S., Trought, M.C.T., and Raw, V. 2009. The flowering process of Vitis vinifera: A review. American Journal of Enology and Viticulture 60:411-434.

CIREN. 1997. Materiales y símbolos. p. 635-659. In Estudio agrológico VII Región. Descripciones de suelos. CIREN Publicación $\mathrm{N}^{\mathrm{o}}$ 117. Centro de Información de Recursos Naturales (CIREN), Santiago, Chile. 
Ferrer, M., Abella, J.M., Sibille, I., Camussi, G., and González-Neves, G. 2004. Determination of bud fertility as a simple method for the determination of harvesting volume in Vitis vinifera L. cv. Tannat, using two pruning systems. OENO One 38:49-53. doi:10.20870/oeno-one.2004.38.1.934.

Fredes, C., Moreno, Y., Ortega, S., and Von Bennewitz, E. 2010. Vine balance: a study case in Carménère grapevines. Ciencia e Investigación Agraria 37:145-150. doi:10.4067/S0718-16202010000100014.

Gil, G., y Pszczólkowski, P. 2007. Viticultura, fundamentos para optimizar producción y calidad. 535 p. Ediciones Universidad Católica de Chile, Santiago, Chile.

Guilpart, N., Metay, A., and Gary, C. 2014. Grapevine bud fertility and number of berries per bunch are determined by water and nitrogen stress around flowering in the previous year. European Journal of Agronomy 54:9-20. doi:10.1016/j.eja.2013.11.002.

López-Miranda, S., Yuste, J., and Lissarrague, J.R. 2004. Effects of bearing unit, spur or cane, on yield components and bud productivity. Vitis 23:47-48.

Martínez de Toda, F. 1991. Biología de la vid: fundamentos biológicos de la viticultura. 346 p. Mundi-Prensa, Madrid, España.

May, P., and Antcliff, A.J. 1963. The effect of shading on fruitfulness and yield in the Sultana. Journal of Horticultural Science 38:85-94. doi:10.1080/00221589.1963.11514062.

May, P., Clingeleffer, P.R., and Brien, C.J. 1976. Sultana (Vitis vinifera L.) canes and their exposure to light. Vitis 14:278-288.

OIV. 2001. OIV descriptor list for grape varieties and Vitis species. $2^{\text {nd }}$ ed. International Organisation of Vine and Wine (OIV), Paris, France.

OIV. 2003. Compendium of internationals methods of wine and must analysis. International Organisation of Vine and Wine (OIV), Paris, France.

Pszczólkowsky, P. 2004. Les millésimes: Chili 2004. Académie Suisse du Vin 42:9-10.

Pszczólkowsky P. 2008. La culture du cépage Carmenère: L'optimum pour la qualité de son vin. Progrès Agricole et Viticole 9:125.

Reynier, A. 2002. Manual de viticultura. 520 p. Ediciones Mundi-Prensa, Madrid, España.

SAG. 2015. Catastro vitícola nacional. Servicio Agrícola y Ganadero (SAG), Santiago, Chile. Available at http://www.sag.gob. $\mathrm{cl} /$ (accessed April 2018).

Sánchez, L.A., and Dokoozlian, N.K. 2005. Bud microclimate and fruitfulness in Vitis vinifera L. American Journal of Enology and Viticulture 56:319-329.

Vaillant-Gaveau, N., Wojnarowiez, G., Petit, A.N., Jacquens, L., Panigai, L., Clément, C., et al. 2014. Relationships between carbohydrates and reproductive development in Chardonnay grapevine: impact of defoliation and fruit removal treatments during four successive growing seasons. Journal International des Sciences de la Vigne et du Vin 48:219-229. doi:10.20870/ oeno-one.2014.48.4.1694.

Wilkie, J.D., Sedgley, M., and Olesen, T. 2008. Regulation of floral initiation in horticultural trees. Journal of Experimental Botany 59:3215-3228. doi:10.1093/jxb/ern188. 